\title{
A study of two methods for estimating plasma fibrinogen and the effect of epsilon aminocaproic acid and protamine
}

\author{
J. C. GIDDINGS AND A. L. BLOOM \\ From the Department of Haematology, University Hospital of Wales, Cardiff
}

SUMMARY Fibrinogen concentrations were determined in normal plasma and in plasma from patients with high and low levels. There was a good correlation between the results of a rapid semi-quantitative fibrinogen titre technique and those of a quantitative assay of coagulable fibrinogen. In normal subjects fibrinogen levels were not significantly influenced by taking blood into epsilon aminocaproic acid (EACA) or by the addition of protamine to plasma. In patients with the defibrination syndrome in whom increased plasma fibrinolysis was not detected, fibrinogen levels were not affected by taking blood into EACA but considerably increased levels were observed after the addition of protamine to plasma. In patients undergoing thrombolytic therapy the fibrinogen levels measured were increased both in blood taken into EACA and in plasma containing protamine. It is suggested that EACA acted by preventing lysis in vitro whilst protamine counteracted abnormal fibrin polymerization. The pattern of results may be of diagnostic importance.

The acute defibrination syndrome is an acquired haemorrhagic disorder associated with reduced levels of plasma fibrinogen. It may occur in a number of clinical conditions and is thought to be due to intravascular activation of the coagulation or fibrinolytic systems. Many patients have thrombocytopenia, and it seems likely that activation of coagulation is the primary event but in thrombolytic therapy hyperplasminaemia occurs. In either case fibrin or fibrinogen breakdown products may interfere with the polymerization of the fibrin monomer. This not only contributes to the bleeding tendency but may also affect coagulation tests, particularly the estimation of fibrinogen. Furthermore, lysis of fibrinogen may occur in vitro, in samples obtained for analysis, thus leading to erroneously low results. In order to prevent this, Nilsson and Olow (1962) took blood into EACA, a potent inhibitor of the fibrinolytic system.

Protamine sulphate accelerates the thrombinfibrinogen reaction even in normal plasma. In the defibrination syndrome the addition of protamine to plasma tends to counteract the abnormal polymerization of fibrin. Fibrinogen values determined in the presence of protamine then tend to be higher than those observed in its absence (Bloom and Campbell, Received for publication 15 October 1970.
1965; Bloom, Boyns, and Wingfield, 1968) and it is possible that this information may be of diagnostic value.

The fibrinogen titre method (Sharp, Howie, Biggs, and Methuen, 1958) has been widely used as a rapid semiquantitative method for the determination of plasma fibrinogen. Sharp and Eggleton (1963) modified this technique to provide evidence of activation of the fibrinolytic system in vivo. Little information is available, however, concerning the correlation of the fibrinogen titre technique with the conventional quantitative assay of coagulable fibrinogen. The object of this paper is to demonstrate this correlation and to determine the effect of the addition of EACA or protamine sulphate on the estimation of fibrinogen in normal and pathological plasma samples. Calcium has been reported to improve abnormal thrombinfibrinogen reactions (Astrup, Brakman, and Nissen, 1965) and the effect of the addition of calcium chloride on fibrinogen determination was also studied. It will be shown that the results of the fibrinogen titre technique correlated with those of the assay of thrombin-coagulable fibrinogen and that with the addition of protamine or EACA a pattern of results emerged which may be of diagnostic importance. 
Materials and Methods

Nine parts of blood were taken into 1 part of $3.8 \%$ $\mathrm{w} / \mathrm{v}$ trisodium citrate and plasma obtained by centrifuging at $3,000 \mathrm{rpm}$ for 10 minutes.

\section{FIBRINOGEN TITRE}

This was performed by the method of Sharp et al (1958). Sevenfold doubling dilutions of $0.5 \mathrm{ml}$ plasma were prepared in $0.9 \%$ saline to give a range of $1: 2$ to $1: 128$. The plasma dilutions were clotted at $37^{\circ} \mathrm{C}$ with $0.1 \mathrm{ml}$ human thrombin, 25 units per $\mathrm{ml}$ (Fibrindex, Ortho), and the highest dilution of plasma containing clot (fibrinogen titre) was noted after 10 minutes.

\section{DEMONSTRATION OF FIBRINOLYSIS}

A second row of tubes was prepared as above except that the plasma was diluted in saline containing EACA at a concentration of $100 \mathrm{mg}$ per $100 \mathrm{ml}$. Saline and EACA-saline dilutions of normal plasma and of equal volumes of patients' and normal plasma (to supply fibrinogen and plasminogen) were also set up. All tubes were incubated at $37^{\circ} \mathrm{C}$ and examined at intervals. Fibrinolysis was indicated by lysis of clots in plasma diluted with saline, in the absence of lysis in control normal plasma and in samples containing EACA.

\section{ESTIMATION OF THROMBIN-COAGULABLE FIBRINOGEN}

This was estimated by a modification of the method of Ratnoff and Menzie (1951). Plasma, $0.2 \mathrm{ml}$, was diluted in $0.5 \mathrm{ml}$ saline and $0.1 \mathrm{ml}$ thrombin, 25 units per $\mathrm{ml}$ (Fibrindex, Ortho), was added. The tube was incubated at $37^{\circ} \mathrm{C}$ for 30 minutes. The fibrin clot was harvested, washed, and the protein content estimated with Folin and Ciocalteu's reagent, after alkaline digestion as described by Varley (1967). The values were not corrected for dilution of the plasma sample with citrate. In this paper this technique is referred to as 'fibrinogen assay'.

EFFECT OF ADDING EACA, PROTAMINE, OR CALCIUM

To test the effect of EACA on the estimation of fibrinogen, blood was taken into trisodium citrate containing EACA at a concentration of $1 \mathrm{~g}$ per $100 \mathrm{ml}$. Nine parts of blood were added to 1 part citrate-EACA so that the final concentration of EACA in blood was $1 \mathrm{mg}$ per $\mathrm{ml}$.

Protamine sulphate (Evans Medical Ltd) was diluted to $1 \mathrm{mg}$ per $100 \mathrm{ml}$ in normal saline and $0.1 \mathrm{ml}$ was added to the tubes containing diluted plasma in the fibrinogen titre tests and fibrinogen assays. Calcium was introduced by dissolving the dried thrombin in $0.025 \mathrm{M}$ calcium chloride and substituting this for the saline solution of thrombino in the fibrinogen titre and assay methods.

Results

Fibrinogen titres and assays were performed on $88 \overline{\frac{7}{7}}$ normal plasma samples. The fibrinogen titres ranged from $1: 32$ to $1: 128$ and the assays ranged from 1850 to $463 \mathrm{mg}$ per $100 \mathrm{ml}$ (mean 307, SD 77). Fibrinogen" titres and assays were also performed on 39 samples from patients with increased plasma fibrinogen $\vec{F}$ levels, and on 43 samples from eight patients with reduced levels. Six of these patients had the acutê⿳亠 defibrination syndrome. Four of these had abruptiq placentae, one had amniotic fluid embolus, and one had suffered multiple injuries. The diagnosis of the defibrination syndrome was based on the presences of a bleeding disorder with low fibrinogen levelso prolonged thrombin clotting time, thrombocytopenia, defective thromboplastin generation, and reduced levels of factor VIII.

Of the other patients in this group, one had received Arvin and one had been treated withN streptokinase. The fibrinogen titres of these eight patients varied from nil to $1: 32$ and the assays fromo nil to $150 \mathrm{mg}$ per $100 \mathrm{ml}$.

When the results of fibrinogen titres of all samples were compared with those of fibrinogen assays 0 general correlation was apparent (Table I). Thu§

\begin{tabular}{|c|c|c|c|c|}
\hline \multirow{2}{*}{$\begin{array}{l}\text { No. of } \\
\text { Plasma } \\
\text { Samples }\end{array}$} & \multirow{2}{*}{$\begin{array}{l}\text { Fibrinogen } \\
\text { Titre }\end{array}$} & \multicolumn{3}{|c|}{ Fibrinogen Assay $(\mathrm{mg} / 100 \mathrm{ml})$} \\
\hline & & Range & Mean & $S D$ \\
\hline $\begin{array}{r}62 \\
34 \\
33 \\
13 \\
7 \\
8 \\
6 \\
7\end{array}$ & $\begin{array}{ll}1 & : 128 \\
1 & : 64 \\
1 & : 32 \\
1 & : 16 \\
1 & : 8 \\
1 & : 4 \\
1 & : 2 \\
0 & \end{array}$ & $\begin{array}{c}300-824 \\
270-409 \\
130-280 \\
77-198 \\
41-70 \\
25-50 \\
9-40 \\
0-10\end{array}$ & $\begin{array}{r}534 \\
342 \\
195 \\
104 \\
57 \\
40 \\
21 \\
3\end{array}$ & $\begin{array}{r}142 \\
51 \\
41 \\
48 \\
11 \\
12 \\
10 \\
5\end{array}$ \\
\hline
\end{tabular}

Table I Distribution of fibrinogen titres with correspond ing fibrinogen assays

samples with low fibrinogen titres had low fibrinogenw assays and the degree of overlap of fibrinogen titres with assays was never more than 1 dilution. The mean assay values plotted on logarithmic scale against corresponding titres produced a straight line; except at the very lowest level $(0-10 \mathrm{mg}$ per $100 \mathrm{ml}$ where the estimation of fibrinogen is probably ver㜓 inaccurate (Fig.).

The results of the presence of EACA, protamine or calcium on the fibrinogen titres and assays of $1 \Phi$ 


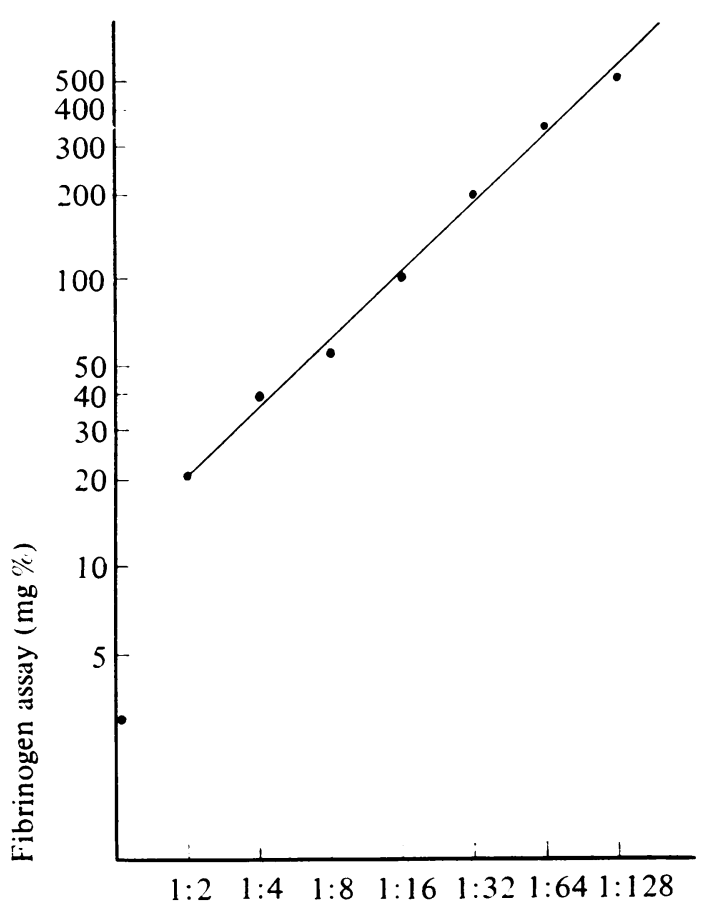

Fibrinogen titre

Fig. Fibrinogen titres of 170 normal and pathological plasma samples plotted against the mean fibrinogen levels ( $\mathrm{mg}$ per $100 \mathrm{ml}$ ) at each titre.

normal plasma samples are shown in Table II. Slightly higher results were observed in the fibrinogen assay with added protamine but none of the differences were statistically significant.

The results of taking blood into EACA or the addition of protamine or calcium to samples with low fibrinogen levels due to the defibrination syndrome or Arvin therapy are shown in Table III. Epsilon aminocaproic acid had no significant effect and the presence of calcium resulted in only small and insignificant elevation of fibrinogen assays. The addition of protamine, however, caused consistent elevation of the fibrinogen titres and highly significant elevation of the fibrinogen assays $(P<0.001)$. In none of these samples was fibrinolytic activity detected in the plasma.

The results of taking blood into EACA or the addition of protamine or calcium to plasma samples from two patients undergoing streptokinase therapy are shown in Table IV. Addition of calcium had little effect except in one sample $\left(\mathrm{MN}_{3}\right)$ where the fibrinogen level was apparently increased. Taking blood into EACA or the addition of protamine, however, resulted in consistently increased fibrinogen titres and much higher assays of coagulable fibrinogen. All these samples showed evidence of increased fibrinolysis. The addition of EACA to plain citrated plasma in the test for fibrinolysis, ie, after separation of the plasma and during its dilution, did not significantly affect the fibrinogen titres but prevented subsequent lysis. Epsilon aminocaproic acid thus prevented fibrinogenolysis and fibrinolysis in vitro but did not promote the formation of fibrin in a manner similar to that of protamine.

The effect of combinations of EACA, protamine, and calcium on the estimation of fibrinogen was not tested.

\section{Discussion}

In the defibrination syndrome or during thrombolytic therapy it may be necessary to perform estimations of plasma fibrinogen urgently. Chemical pre-

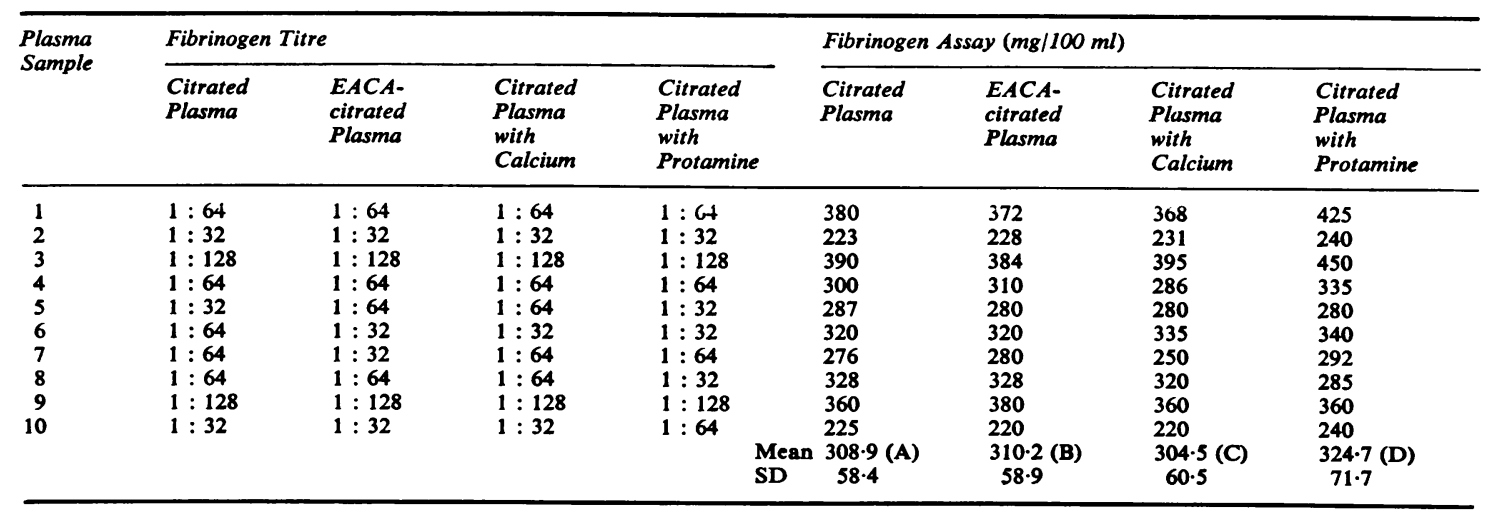

Table II Fibrinogen titres and corresponding fibrinogen assays of normal plasma samples 


\begin{tabular}{|c|c|c|c|c|c|c|c|c|}
\hline \multirow{2}{*}{$\begin{array}{l}\text { Plasma } \\
\text { Sample }\end{array}$} & \multicolumn{4}{|c|}{ Fibrinogen Titre } & \multicolumn{4}{|c|}{ Fibrinogen Assay (mg/100 ml) } \\
\hline & $\begin{array}{l}\text { Citrated } \\
\text { Plasma }\end{array}$ & $\begin{array}{l}\text { EACA- } \\
\text { citrated } \\
\text { Plasma }\end{array}$ & $\begin{array}{l}\text { Citrated } \\
\text { Plasma } \\
\text { with } \\
\text { Calcium }\end{array}$ & $\begin{array}{l}\text { Citrated } \\
\text { Plasma } \\
\text { with } \\
\text { Protamine }\end{array}$ & $\begin{array}{l}\text { Citrated } \\
\text { Plasma }\end{array}$ & $\begin{array}{l}\text { EACA- } \\
\text { citrated } \\
\text { Plasma }\end{array}$ & $\begin{array}{l}\text { Citrated } \\
\text { Plasma } \\
\text { with } \\
\text { Calcium }\end{array}$ & $\begin{array}{l}\text { Citrated } \\
\text { Plasma } \\
\text { with } \\
\text { Protamine }\end{array}$ \\
\hline $\begin{array}{l}\mathbf{M W}_{1} \\
\mathbf{M W}_{2} \\
\mathbf{M W}_{3} \\
\mathrm{IK}_{1} \\
\mathrm{IK}_{2} \\
\mathrm{BP}_{1} \\
\mathrm{BP}_{3} \\
\mathrm{CE}_{1} \\
\mathrm{CE}_{2} \\
\text { P.B. } \\
\text { L.G. } \\
\text { B.H. }\end{array}$ & $\begin{array}{l}0 \\
0 \\
0 \\
1: 8 \\
0 \\
0 \\
1: 16 \\
1: 2 \\
1: 2 \\
1: 2 \\
1: 2 \\
1: 4 \\
1: 4\end{array}$ & $\begin{array}{l}0 \\
0 \\
0 \\
1: 16 \\
0 \\
0 \\
1: 16 \\
1: 2 \\
1: 2 \\
1: 2 \\
1: 4 \\
1: 4\end{array}$ & $\begin{array}{l}0 \\
0 \\
1: 2 \\
1: 16 \\
0 \\
0 \\
1: 16 \\
1: 4 \\
1: 2 \\
1: 2 \\
1: 8 \\
1: 4\end{array}$ & $\begin{array}{ll}1: 4 \\
1: 8 \\
1: 16 \\
1: 32 \\
1: 8 \\
1: 16 \\
1: 32 \\
1: 8 \\
1: 16 \\
1: 32 \\
1: 16 \\
1: 32\end{array}$ & $\begin{array}{r}0 \\
0 \\
0 \\
67 \\
0 \\
0 \\
150 \\
40 \\
25 \\
9 \\
40 \\
25 \\
29 \cdot 7(\mathrm{~A}) \\
43.7\end{array}$ & $\begin{array}{c}0 \\
0 \\
0 \\
53 \\
0 \\
10 \\
150 \\
45 \\
20 \\
9 \\
40 \\
40 \\
30 \cdot 6(B) \\
42 \cdot 5\end{array}$ & $\begin{array}{c}0 \\
9 \\
9 \\
80 \\
0 \\
10 \\
150 \\
60 \\
40 \\
20 \\
70 \\
35 \\
40 \cdot 3(\mathrm{C}) \\
44 \cdot 2\end{array}$ & $\begin{array}{c}40 \\
60 \\
85 \\
120 \\
70 \\
80 \\
200 \\
90 \\
105 \\
140 \\
95 \\
100 \\
98 \cdot 8(\mathrm{D}) \\
41 \cdot 4\end{array}$ \\
\hline \multicolumn{9}{|c|}{$\begin{array}{l}\text { Table III Fibrinogen titres and corresponding fibrinogen assays on plasma samples obtained from patients with the } \\
\text { defibrination syndrome }\end{array}$} \\
\hline \multirow{2}{*}{$\begin{array}{l}\text { Plasma } \\
\text { Sample }\end{array}$} & \multicolumn{4}{|c|}{ Fibrinogen Titre } & \multicolumn{4}{|c|}{ Fibrinogen Assay $(\mathrm{mg} / 100 \mathrm{ml})$} \\
\hline & $\begin{array}{l}\text { Citrated } \\
\text { Plasma }\end{array}$ & $\begin{array}{l}\text { EACA- } \\
\text { citrated } \\
\text { Plasma }\end{array}$ & $\begin{array}{l}\text { Citrated } \\
\text { Plasma } \\
\text { with } \\
\text { Calcium }\end{array}$ & $\begin{array}{l}\text { Citrated } \\
\text { Plasma } \\
\text { with } \\
\text { Protamine }\end{array}$ & $\begin{array}{l}\text { Citrated } \\
\text { Plasma }\end{array}$ & $\begin{array}{l}\text { EACA- } \\
\text { citrated } \\
\text { Plasma }\end{array}$ & $\begin{array}{l}\text { Citrated } \\
\text { Plasma } \\
\text { with } \\
\text { Calcium }\end{array}$ & $\begin{array}{l}\text { Citrated } \\
\text { Plasma } \\
\text { with } \\
\text { Protamine }\end{array}$ \\
\hline $\begin{array}{l}\mathrm{MN}_{1} \\
\mathrm{MN}_{2} \\
\mathrm{MN}_{3} \\
\mathrm{NM}_{1} \\
\mathrm{NM}_{2} \\
\mathrm{NM}_{3}\end{array}$ & $\begin{array}{l}1: 4 \\
1: 8 \\
0 \\
1: 8 \\
1: 4 \\
1: 8\end{array}$ & $\begin{array}{l}1: 32 \\
1: 32 \\
1: 32 \\
1: 128 \\
1: 64 \\
1: 32\end{array}$ & $\begin{array}{l}1: 4 \\
1: 8 \\
1: 8 \\
1: 4 \\
1: 4 \\
1: 8\end{array}$ & $\begin{array}{l}1: 32 \\
1: 32 \\
1: 64 \\
1: 128 \\
1: 128 \\
1: 64\end{array}$ & $\begin{array}{l}20 \\
50 \\
10 \\
63 \\
40 \\
55\end{array}$ & $\begin{array}{l}225 \\
220 \\
220 \\
460 \\
384 \\
260\end{array}$ & $\begin{array}{l}25 \\
60 \\
95 \\
48 \\
36 \\
45\end{array}$ & $\begin{array}{l}250 \\
250 \\
300 \\
490 \\
390 \\
285\end{array}$ \\
\hline
\end{tabular}

Table IV Fibrinogen titres and corresponding fibrinogen assays on plasma samples obtained from patients on streptokinase therapy

cipitation (Parfentjev, Johnson, and Cliffton, 1953) and immunological methods (eg, FI test, Hyland) can be performed rapidly, but the results may correlate poorly with those of tests which measure coagulable fibrinogen (Sharp et al, 1958; Bloom and Campbell, 1965). It is probable that both the precipitation and immunological methods measure breakdown products of fibrin and fibrinogen or soluble fibrin polymers which do not coagulate. On the other hand these derivatives may interfere with the polymerization of normal fibrin monomer and so reduce the apparent levels of coagulable fibrinogen. It seems iikely, however, that the concentration of normally coagulable fibrinogen is most relevant to haemostasis.

The present study has confirmed that the fibrinogen titre technique described by Sharp et al (1958) is a reliable, rapid semi-quantitative method for the estimation of coagulable fibrinogen. The results with this method were comparable, within the limits of the technique, with those observed using the method of Ratnoff and Menzie (1951), a technique which is too time consuming for emergency use.

In normal plasma the presence of EACA, protamine, or calcium had little effect on the estimation of fibrinogen. In patients with the defibrination syn-ô drome and those undergoing thrombolytic therapy, however, the addition of protamine caused con-응 siderable increase in the measured levels of coagul- $D$ able fibrinogen. In these conditions it is likely that? the polymerization of fibrin is abnormal due to the presence of fibrin or fibrinogen split products. (Fletcher, Alkjaersig, and Sherry, 1962) or soluble $\mathcal{O}^{2}$ intermediary fibrin polymer (Shainoff and Page, ${ }_{\mathrm{C}}$ 1962). In the present study it is probable that prota-O mine more or less corrected the abnormal polymerization and that this accounted for the observed increase of fibrinogen levels.

Epsilon aminocaproic acid is a potent inhibitor of 0 the fibrinolytic system. Higher fibrinogen levels were observed when blood from patients treated with $\stackrel{\odot}{\triangle}$ streptokinase was taken into EACA than when it $\stackrel{0}{\circ}$ was taken into plain citrate. Unlike protamine, 
EACA did not promote the formation of fibrin but seemed to act by preventing fibrinogenolysis or fibrinolysis in vitro before and during the estimations. Epsilon aminocaproic acid did not affect the fibrinogen levels in patients with the defibrination syndrome but in these patients increased fibrinolysis was not detected. It seems desirable, however, that blood samples for fibrinogen estimation should be taken into anticoagulant containing EACA or some other fibrinolytic inhibitor when increased fibrinolysis is suspected, in order to prevent lysis in vitro.

The addition of calcium had no significant effect on fibrinogen titres or assays in the present study but its presence rendered the clot more opaque and less friable. It was then easier to harvest in the Ratnoff and Menzie method. In this manner calcium could possibly increase the accuracy of the technique, particularly at low fibrinogen levels. The thrombin-calcium chloride mixture thus constituted a convenient reagent for fibrinogen assays.

Although it is probable that the level of fibrinogen measured in the absence of protamine is most relevant to haemostasis a certain pattern of results emerged in the present study. In normal plasma the addition of protamine, EACA, or calcium had no significant effect on the measurement of fibrinogen. In the defibrination syndrome, when increased plasma fibrinolysis was not detected, the presence of EACA or calcium had no significant effect but higher fibrinogen levels were observed after the addition of protamine. In patients undergoing thrombolytic therapy the presence of calcium also had little effect but higher fibrinogen levels were observed in blood taken into EACA and after the addition of protamine.

In the acute defibrination syndrome it is necessary to distinguish rapidly between disseminated intravascular coagulation and increased fibrinolysis because inappropriate treatment may be harmful. As a result of this work we suggest that the following simple tests should be initially performed.

Blood is taken into EACA-citrate and into plain citrate and the fibrinogen titre performed on each sample. The fibrinogen titre with protamine is performed on the plain citrated sample. Whilst these tests are developing, a thrombin clotting time is determined and a platelet count set up, the former giving rapid information concerning the presence or absence of defibrination.

If the fibrinogen titre in plain citrated plasma is lower than in EACA-citrated plasma increased fibrinolysis is suspected and is confirmed appropriately (see Methods, and Hardisty, Ingram, and Sharp, 1964). If, on the other hand, the fibrinogen titre is reduced in both EACA-citrated and plain citrated plasma but is higher in the presence of protamine the defect is more likely to be due to intravascular coagulation. This is confirmed in the presence of thrombocytopenia. We do not claim that this scheme is exhaustive and if time permits other investigations (Hardisty et al, 1964) should be performed. The scheme does, however, allow a reasonably rapid assessment which can easily be introduced into laboratory routine.

\section{References}

Astrup, T., Brakman, P., and Nissen, U. (1965). The estimation of fibrinogen. A revision. Scand. J. clin. Lab. Invest., 17, 57-65.

Bloom, A. L., Boyns, A. R., and Wingfield, J. G. (1968). Obstetric defibrination syndrome with abnormal thrombin-fibrinogen reaction and immunologically reactive altered fibrinogen in serum. Scand. J. Haemat., 5, 26-34.

Bloom, A. L., and Campbell, N. (1965). Defibrination syndrome with defective thrombin-fibrinogen reaction reversible by protamine. J. clin. Path., 18, 786-789.

Fletcher, A. P., Alkjaersig, N., and Sherry, S. (1962). Pathogenesis of the coagulation defect developing during pathological plasma proteolytic ('fibrinolytic') states. 1. The significance of fibrinogen proteolysis and circulating fibrinogen breakdown products. J. clin. Invest., 41, 896-916.

Hardisty, R. M., Ingram, G. I. C., and Sharp, A. A. (1964). The laboratory investigation and control of the defibrination syndrome. Ass. clin. Path., Broadsheets, 48.

Nilsson, I. M., and Olow, B. (1962). Determination of fibrinogen and fibrinogenolytic activity. Thrombos. Diathes. haemorrh. (Stuttg.), 8, 297-310.

Parfentjev, I. A., Johnson, M. L., and Cliffton, E. E. (1953). The determination of plasma fibrinogen by turbidity with ammonium sulphate. Arch. Biochem., 46, 470-480.

Ratnoff, O. D., and Menzie, A. B. (1951). A new method for the determination of fibrinogen in small samples of plasma. J. Lab. clin. Med., 37, 316-320.

Shainoff, J. R., and Page, I. H. (1962). Significance of cryoprofibrin in fibrinogen-fibrin conversion. J. exp. Med., 116, 687-707.

Sharp, A. A., and Eggleton, M. J. (1963). Haematology and the extracorporeal circulation. J. clin. Path., 16, 551-557.

Sharp, A. A., Howie, B., Biggs, R., and Methuen, D. T. (1958). Defibrination syndrome in pregnancy: value of various diagnostic tests. Lancet, 2, 1309-1313.

Varley, H. (1967). Practical Clinical Biochemistry, 4th ed. Heinemann, London. 